\title{
Business Process Reengineering Pada Perusahaan PDAM Kabupaten Mojokerto Untuk Meningkatkan Kinerja Bisnis Perusahaan
}

\author{
Faridho Fajar Rozaqi ${ }^{\star 1}$, Wildan Suharso ${ }^{2}$, llyas Nuryasin ${ }^{3}$ \\ 1,2,3Teknik Informatika/Universitas Muhammadiyah Malang \\ Faridhofajar12@gmail.com¹, Wsuharso@umm.ac.id ${ }^{2}$, llyas@umm.ac.id ${ }^{3}$
}

\begin{abstract}
Abstrak
Semakin berkembangnya dunia bisnis dan semakin kompleksnya transaksi serta semakin luasnya jangkauan usaha sebuah perusahaan, maka kebutuhan perusahaan untuk mengoptimalkan setiap proses bisnis harus lebih efektif dan efisien di areanya [6]. Maka dari itu perubahan proses bisnis terkadang perlu dilakukan untuk mengganti sistem yang lama dengan sistem yang baru. Perubahan proses bisnis yang signifikan ini disebut Business Process Reenginering. Konsep BPR (Business Process Reengineering) sendiri adalah merupakan sebuah konsep rekontruksi ulang dengan melakukan tindakan secara dramatis dan radikal sehingga dapat menghasilkan perbaikan proses, penghematan biaya, serta peningkatan kecepatan [1]. Perusahaan Daerah Air Minum (PDAM) Kabupaten Mojokerto merupakan salah satu perusahaan yang bekerja dibidang jasa penyedia air untuk kebutuhan sehari-hari. Struktur organisasi secara umum terdiri dari Pimpinan/Direktur, Bagian Hubungan Langganan dan Pemasaran, Bagian Perencanaan, Bagian Produksi dan Distribusi, Bagian Umum dan Kepegawaian, dan Bagian Akuntansi dan Keuangan. Masalah yang terjadi adalah terlalu banyak proses yang tidak optimal, waktu yang terlalu lama untuk penanganan konsumen, pencatatan yang masih manual, dan terlalu banyak mengeluarkan biaya untuk sebagian proses. Berdasarkan masalah diatas, Bisnis proses PDAM Kab. Mojokerto yang perlu dirubah atau direengineering adalah proses bisnis pemasangan baru. Dengan Business Process Reenginering mampu merubah proses yang lama ke proses yang baru yaitu pada tahapan rekomendasi sehingga mendapatkan proses yang lebih efisien dalam hal pelayanan waktu.
\end{abstract}

Kata Kunci: Business Process Reenginering, PDAM Kabupaten Mojokerto, Reengineering, Legacy System

\begin{abstract}
The development of the business world and is getting more complex business transactions and expansion in the size of a company, demand for the company to optimize any process of business must be more effective and efficient in area .So that the change of business process sometimes need is to replace the old with a new system. A significant change of business process is called business process reenginering. Bpr concept (business process reengineering) are is a concept rekontruksi remake with take action dramatically and radicals which can lead to repair processes, cost savings, and increasing speed. PDAM district mojokerto is one of the companies working in the fields of service providers to the needs of water every day. The organizational structure in general / consisting of the director, the subscription and marketing, planning, production and Distribution, general and human resources, and accounting and finance. The problems is that too much process that is not optimal, for too long the consumer, manual still recording, and too much of the cost. Based on the above problems, the business process of PDAM Mojokerto that needs to be changed or reengineered is a new installation business process. With Business Process Reengineering can change the old process into a new process. that is on renewal so as to get a more efficient process in terms of time service.
\end{abstract}

Keywords: Business Process Reenginering, PDAM Kabupaten Mojokerto, Reengineering, Legacy System

\section{Pendahuluan}

Semakin berkembangnya dunia bisnis dan semakin kompleksnya transaksi serta semakin luasnya jangkauan usaha sebuah perusahaan, maka kebutuhan perusahaan untuk 
mengoptimalkan setiap proses bisnis harus lebih efektif dan efisien di areanya [6]. Maka dari itu perubahan proses bisnis terkadang perlu dilakukan untuk mengganti sistem yang lama dengan sistem yang baru. Perubahan proses bisnis yang signifikan ini disebut Business Process Reenginering.

Sedangkan munculnya Istilah Reengineering pertama kali pada tahun 1900-an dibidang teknologi informasi (TI) oleh Michael Hammer yang menerbitkan sebuah artikel di Harvard Business Review, yaitu tentang perlunya dilakukan perubahan fundamental pada organisasi/perusahaan, diringingi dengan terjadinya perubahan global dalam bidang ekonomi, persaingan yang semakin ketat, dan perubahan permintaan kebutuhan customer/pelanggan [3].

Teknologi informasi (TI) adalah teknologi komputer yang disatukan. dengan teknologi telekomunikasi. sehingga teknologi informasi ( $\mathrm{Tl}$ ) adalah teknologi yang berhubungan dengan sebuah pengolahan data dan menjadi sebuah informasi. Teknologi informasi berperan penting dalam Business Process Reenginering dikarenakan, (TI) mampu merubah. aturan lama yang menghalangi orang dalam melakukan pekerjaannya [8].

Teknologi informasi juga bermanfaat untuk sebuah perusahaan atau organisasi, yaitu dengan peningkatan kepuasan pelanggan, pengurangan. penggunaan dokumen kertas, perbaikan. proses pengambilan keputusan. Dengan perkembangan. teknologi. informasi saat ini juga mempunyai banyak peran yang mampu merubah cara-cara yang lama dalam pengelolaan proses bisnis suatu organisasi. terutama pada manajemen data dan sebuah informasi. Sebuah sistem informasi mampu menyimpan informasi. dalam jumlah yang besar dan bisa diakses dengan mudah dimana saja dan kapan saja [2].

Business Process Reengineering adalah konsep untuk. merubah ulang bisnis proses yang memiliki titik kelemahan pada proses bisnisnya. lebih efisien dan kompetitif merupakan tujuan untuk memperbaiki kinerja organisasi. Business Process Reengineering bisa digunakan atau diaplikasikan untuk memperbaiki kinerja. sebuah perusahaan, instansi, organisasi dan perusahaan [3]. Peningkatan yang signifikan dari segi biaya, kecepatan, dan pelayanan adalah. salah satu hasil dari Business Process Reengineering [4].

Konsep BPR. (Business Process Reengineering) adalah. Konsep untuk merekontruksi ulang dengan. tindakan secara dramatis dan radikal. sehingga. BPR bisa menghasilkan penghematan biaya, perbaikan proses, dan peningkatan kecepatan dalam menjalankan proses bisnis [1]. Business Process Reengineering memiliki hal yang mendasar yaitu pemilik/pemimpin sebuah perusahaan atau organisasi harus. memiliki strategi yang efisien dan keberanian untuk meningkatkan kinerja perusahaan yang dimiliki dari segala aspek, pada akhirnya akan menjadi penentu berkembangnya sebuah perusahaan atau organisasi [5].

Beberapa penelitian memberikan hasil yang memuaskan dengan menggunakan konsep BPR (Business Process Reengineering), yaitu memberikan perubahan yang signifikan. dengan meningkatnya kinerja perusahaan atau organisasi. Kisah keberhasilan implementasi Business Process Reengeneering di Kejaksaan Negeri Batu yaitu rekayasa ulang layanan permintaan informasi. Hasil akhir meningkatkan efisiensi throughput dari 10,61\% pada proses sebelumnya menjadi $100 \%$ pada proses rancang ulang [7].

Perusahaan Daerah Air Minum Kabupaten Mojokerto (PDAM) merupakan salah satu perusahaan yang bekerja dibidang jasa penyedia air untuk kebutuhan sehari-hari. Struktur organisasi secara umum terdiri dari Pimpinan/Direktur, Bagian Hubungan Langganan dan Pemasaran, Bagian Perencanaan, Bagian Produksi dan Distribusi, Bagian Umum dan Kepegawaian, dan Bagian Akuntansi dan Keuangan.

Dari segi legacy sistem saat ini pada Perusahaan Daerah Air Minum (PDAM) Kabupaten Mojokerto. Ketika dilakukan analisa proses bisnis melalui wawancara tanggal 6 Maret 2018 dengan Pegawai Bidang IT. Sistem legacyst yastng berlangsung sudah lebih dari 10 tasthun. Penggunaan aplikastsi untuk membstantu proses bisnis perusahaan yaitu bestrupa aplikstasi office dan beberapa aplikasi manajemen yang bisa dikembangkan lagi. Proses bisnis yang ada ketika dilakukan analisa banyak waktu dan biaya contohnya dalam menggunakan banyak pemakaian kertas sehingga kondisi ini tidak efisien.

Beberapa Hipotesis dari bisnis proses PDAM Kab. Mojokerto yang perlu dirubah atau direengineering adalah proses bisnis pemasangan baru dimana pada prosesnya terdapat birokrasi yang seharusnya bisa dipersingkat dan masih menggunakan cara konvensional karena tidak didukung teknologi informasi yang memadai yaitu pada proses pemasangan baru kendala yang sering terjadi yaitu adanya kehabisan stok bahan untuk pemasangan, dimana untuk pengecekan dilakukan secara manual dengan mencari ke gudang, selain itu juga terdapat terlalu

REPOSITOR, Vol. 2, No. 5, Mei 2020: 635-648 
lamanya pengerjaan dilapangan untuk pemasangan baru disebabkan banyak faktor mulai dari sumber daya manusia yang terbatas serta medan yang di hadapi terlalu sulit.

\section{Metode Penelitian}

Dalam penelitian ini akan dilakukan penerapan Metode BPR (Business Process Reengineering) yang ditunjukkan pada Gambar 1 dibawah ini.

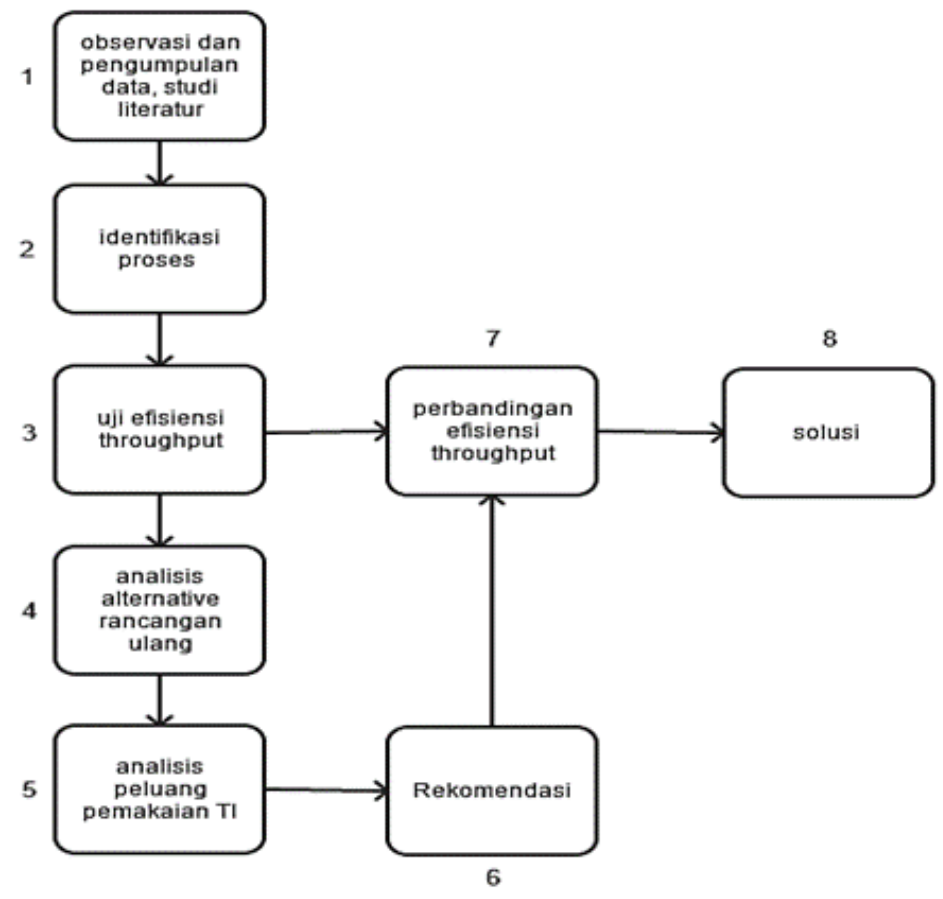

Gambar 1. Metode BPR (Business Process Reengineering)

Gambar 1 menggambarkan tahapan metode BPR (Business Process Reengineering) dimulai dari tahap pengumpulan data hingga tahap solusi. Pada tahap ke tiga yaitu uji efisiensi Throughput di uji menggunakan Persamaan 1 dibawah ini.

$$
\text { efisiensi throughput }=\frac{\text { waktu proses bukan tunda }}{\text { total waktu dalam sistem }} \times 100 \%
$$

Pengujian efisiensi throughput dilakukan berdasarkan hasil perhitungan waktu kinerja proses bisnis menggunakan standar ASME selanjutnya dilakukan perbandingan nilai hasil efisiensi throughput antara hasil efisiensi proses bisnis awal dengan hasil rekayasa ulang proses bisnis yang baru.

\section{Hasil Penelitian dan Pembahasan 3.1 Pengumpulan Data}

Dalam metode pengumpulan data dan pencarian data untuk memenuhi keperluan yang dibutuhkan. Data diperoleh dari observasi dan wawancara ke PDAM Kabupaten Mojokerto serta melakukan studi literature yang berhubungan dengan BPR (Business Process Reengineering). Pada proses observasi ke PDAM Kabupaten Mojokerto penulis mengamati proses yang sedang berjalan dan mengetahui peran perbidang dalam menjalankan proses-proses tersebut. Hal ini perlu dilakukan agar nantinya dapat dilakukan analisis terhadap proses yang sedang berjalan dan nantinya dapat menemukan rancangan proses baru yang akan dibuat.

Pada proses wawancara yang dilakukan pada tanggal 6 Maret 2018 dan 21 September 2018 telah ditemukan yaitu Legacy sistem pada PDAM Kabupaten Mojoketo sudah berjalan selama lebih dari 10 tahun. Proses bisnis yang berhubungan dengan hubungan pelanggan pada PDAM Kabupaten Mojokerto masih banyak dilakukan secara manual. Pada proses bisnis pemasangan baru, penanganan keluhan pelanggan dan survey pelanggan ditemukan titik kelemahan dari segi biaya, pelayanan dan kecepatan. 


\subsection{Identifikasi Proses}

Pengumpulan data yang dilakukan di PDAM Kabupaten Mojokerto dengan cara observasi dan wawancara dengan pegawai IT ditemukan proses pemasangan baru diidentifikasi mempunyai titik kelemahan dari segi biaya, pelayanan dan kecepatan. Proses Bisnis Pemasangan baru: bagian yang terlibat dalam proses ini yaitu pelanggan, bagian loket/administrasi, hubungan dan layanan, dan bagian distribusi pemasangan. Alur proses bisnis pemasangan baru ditunjukan pada Gambar 2.

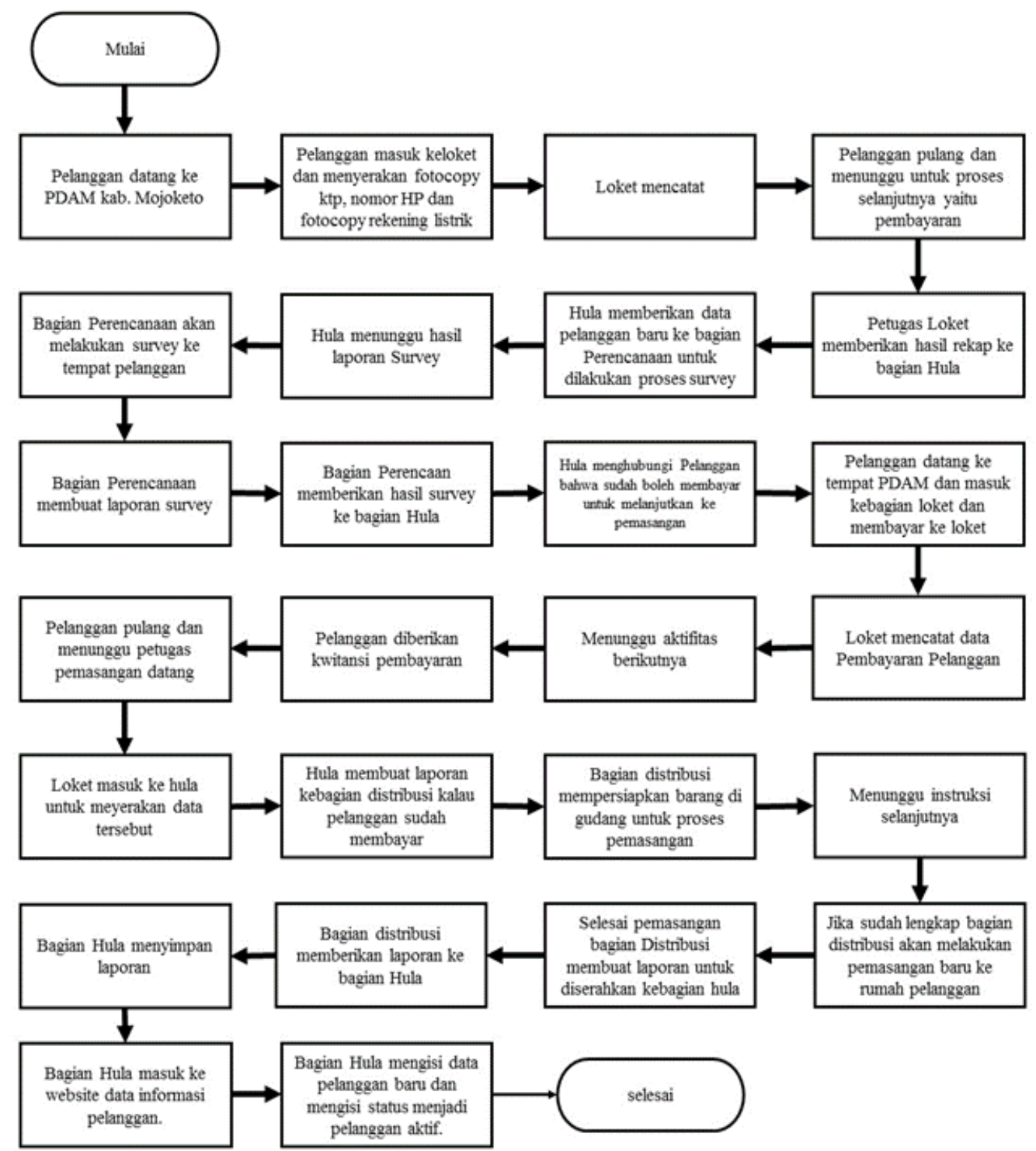

Gambar 2. Proses Bisnis Pemasangan Baru

\subsection{Uji Efisiensi Throughput}

Pada tahap ini dilakukan pengujian proses bisnis PDAM Kabupaten Mojokerto. Proses yang mempunyai kelemahan dari segi waktu pelayanan diuji dengan menggunakan uji efisiensi throughput yaitu uji waktu pelayanan secara keseluruhan. Dipetakan dengan peta standar ASME (American Society of Mechanical Engineers).

Tujuan dilakukan uji efisiensi throughput dan pemetaan standar ASME (American Society of Mechanical Engineers) untuk mengetahui dan mengukur kinerja persentase waktu pelayanan secara keseluruhan, yang nantinya akan dibandingkan dengan proses bisnis rekomendasi dari segi model dan hasil. Berikut ini adalah pemetaan standar ASME dan uji efisiensi throughput dari proses bisnis pemasangan baru PDAM Kabupaten Mojokerto. 


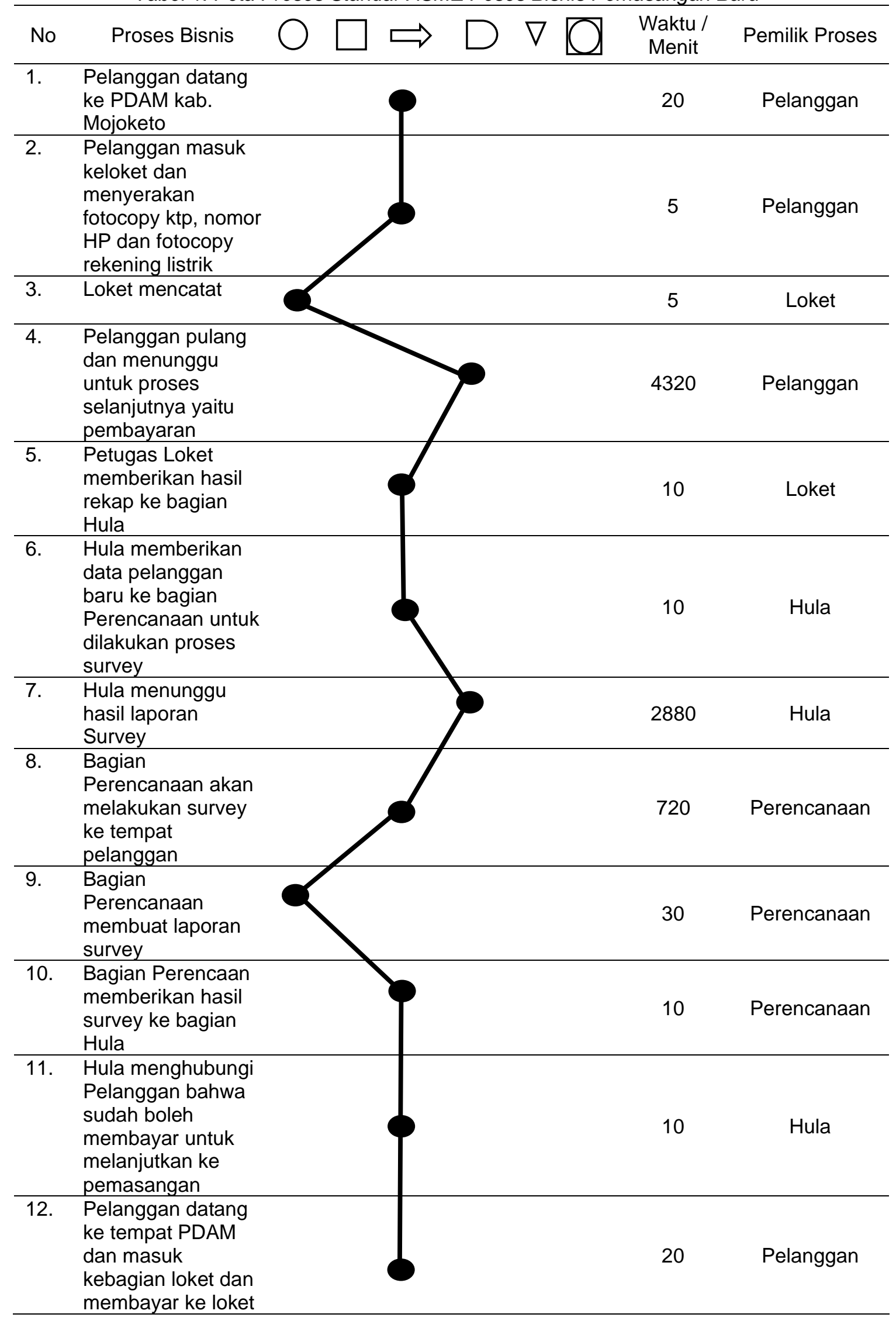




\begin{tabular}{|c|c|c|c|}
\hline \multirow{2}{*}{$\frac{640}{13 .}$} & & \multicolumn{2}{|c|}{ ISSN: 2714-7975; E-ISSN: 2716-1382 } \\
\hline & $\begin{array}{l}\text { Loket mencatat } \\
\text { data Pembayaran } \\
\text { Pelanggan }\end{array}$ & 10 & Loket \\
\hline 14. & $\begin{array}{l}\text { Menunggu aktifitas } \\
\text { berikutnya }\end{array}$ & 10 & Pelanggan \\
\hline 15. & $\begin{array}{l}\text { Pelanggan } \\
\text { diberikan kwitansi } \\
\text { pembayaran }\end{array}$ & 5 & Pelanggan \\
\hline 16. & $\begin{array}{l}\text { Pelanggan pulang } \\
\text { dan menunggu } \\
\text { petugas } \\
\text { pemasangan } \\
\text { datang }\end{array}$ & 1440 & Pelanggan \\
\hline 17. & $\begin{array}{l}\text { Loket masuk ke } \\
\text { hula untuk } \\
\text { menyerakan data } \\
\text { tersebut }\end{array}$ & 10 & Loket \\
\hline 18. & $\begin{array}{l}\text { Hula membuat } \\
\text { laporan kebagian } \\
\text { distribusi kalau } \\
\text { pelanggan sudah } \\
\text { membayar }\end{array}$ & 10 & Hula \\
\hline 19. & $\begin{array}{l}\text { Bagian distribusi } \\
\text { mempersiapkan } \\
\text { barang di gudang } \\
\text { untuk proses } \\
\text { pemasangan }\end{array}$ & 60 & Distribusi \\
\hline 20. & $\begin{array}{l}\text { Menunggu instruksi } \\
\text { selanjutnya }\end{array}$ & 180 & Distribusi \\
\hline 21. & $\begin{array}{l}\text { Jika sudah lengkap } \\
\text { bagian distribusi } \\
\text { akan melakukan } \\
\text { pemasangan baru } \\
\text { ke rumah } \\
\text { pelanggan }\end{array}$ & 2880 & Disribusi \\
\hline 22. & $\begin{array}{l}\text { Selesai } \\
\text { pemasangan } \\
\text { bagian Distribusi } \\
\text { membuat laporan } \\
\text { untuk diserahkan } \\
\text { kebagian hula }\end{array}$ & 20 & Distribusi \\
\hline 23. & $\begin{array}{l}\text { Bagian distribusi } \\
\text { memberikan } \\
\text { laporan ke bagian } \\
\text { Hula }\end{array}$ & 5 & Distribusi \\
\hline 24. & $\begin{array}{l}\text { Bagian Hula } \\
\text { menyimpan laporan }\end{array}$ & 5 & Hula \\
\hline 25. & $\begin{array}{l}\text { Bagian Hula masuk } \\
\text { ke website data } \\
\text { informasi } \\
\text { pelanggan. }\end{array}$ & 5 & Hula \\
\hline 26. & $\begin{array}{l}\text { Bagian Hula } \\
\text { mengisi data } \\
\text { pelanggan baru } \\
\text { dan mengisi status } \\
\text { menjadi pelanggan } \\
\text { aktif. }\end{array}$ & 5 & Hula \\
\hline
\end{tabular}

REPOSITOR, Vol. 2, No. 5, Mei 2020: 635-648 
Jumlah Tahap

$\begin{array}{cccccc}7 & 0 & 13 & 5 & 1 & 0 \\ 85 & 0 & 3770 & 8830 & 5 & 0\end{array}$

$0 \quad 12690$

Tabel 1 adalah tabel peta standar ASME dari proses pemasangan baru pada PDAM Kabupaten Mojokerto dimana pada pemetaan standar ASME ini terdapat tahap proses, simbol proses, wkt/mnt proses dan pemilik proses. Pemilik proses pada tabel standar ASME ini adalah pelanggan, petugas loket dan Hubungan dan langganan serta bagian distribusi. Langkah selanjutnya dilakukan pengujian efisiensi throughput. Uji untuk mengukur kinerja waktu pelayanan secara keseluruhan dari hasil pemetaan standar ASME proses pemasangan baru seperti berikut.

$$
\begin{gathered}
\text { efisiensi throughput }=\frac{3860}{12690} \times 100 \% \\
=30,41 \%
\end{gathered}
$$

Hasil dari uji efisiensi throughput dari pemetaan standar ASME pada proses pemasangan baru. Rumus efisiensi throughput adalah waktu proses bukan tunda dibagi dengan total waktu dalam sistem dikali dengan $100 \%$. Nilai 3860 adalah proses yang tidak mengalami waktu tunda sedangkan nilai 12680 adalah semua proses termasuk yang mengalami waktu tunda dengan simbol delay. Hasil dari uji efisiensi throughput pada proses pemasangan baru adalah $30,41 \%$ dan sisa waktu yaitu $69,59 \%$ pada proses pemasangan baru tidak berjalan.

\subsection{Analisis Alternative Rancangan Ulang}

Pada tahap ini dilakukan analisis alternative rancangan ulang yaitu proses bisnis yang ditemukan memiliki kelemahan dirancang secara berbeda dengan cara melakukan penyempurnaan desain proses yaitu menyederhanakan proses, mengurangi waktu proses, menghilangkan kesalahan dalam proses, standarisasi dan otomatisasi pada proses. Tabel 2 berikut ini proses bisnis pada PDAM Kabupaten Mojokerto yang dilakukan penyempurnaan desain proses.

\begin{tabular}{|c|c|c|}
\hline No. & Tahap Proses & Langkah Penyempurnaan \\
\hline 1. & Pelanggan datang ke PDAM kab. Mojoketo & $\begin{array}{l}\text { Eliminasi dan automate } \\
\text { pelanggan masuk website } \\
\text { pemasangan baru }\end{array}$ \\
\hline 2. & $\begin{array}{l}\text { Pelanggan masuk keloket dan menyerakan } \\
\text { fotocopy ktp, nomor HP dan fotocopy rekening } \\
\text { listrik }\end{array}$ & Eliminasi \\
\hline 3. & Loket mencatat & Eliminasi \\
\hline 4. & $\begin{array}{l}\text { Pelanggan pulang dan menunggu untuk proses } \\
\text { selanjutnya yaitu pembayaran }\end{array}$ & Eliminasi \\
\hline 5. & $\begin{array}{l}\text { Petugas Loket memberikan hasil rekap ke } \\
\text { bagian Hula }\end{array}$ & \\
\hline 6. & $\begin{array}{l}\text { Hula memberikan data pelanggan baru ke } \\
\text { bagian Perencanaan untuk dilakukan proses } \\
\text { survey }\end{array}$ & \\
\hline 7. & Hula menunggu hasil laporan Survey & Eliminasi \\
\hline 8. & $\begin{array}{l}\text { Bagian Perencanaan akan melakukan survey } \\
\text { ke tempat pelanggan }\end{array}$ & \\
\hline 9. & Bagian Perencanaan membuat laporan survey & Eliminasi \\
\hline 10. & $\begin{array}{l}\text { Bagian Perencaan memberikan hasil survey ke } \\
\text { bagian Hula }\end{array}$ & Eliminasi \\
\hline 11. & $\begin{array}{l}\text { Hula menghubungi Pelanggan bahwa sudah } \\
\text { boleh membayar untuk melanjutkan ke } \\
\text { pemasangan }\end{array}$ & Eliminasi \\
\hline 12. & $\begin{array}{l}\text { Pelanggan datang ke tempat PDAM dan masuk } \\
\text { kebagian loket dan membayar ke loket }\end{array}$ & Automate \\
\hline
\end{tabular}

Tabel 2. Penyempurnaan Proses Bisnis Pemasangan Baru

Business Process Reengineering Pada Perusahaan PDAM... Faridho Fajar Rozaqi, Wildan Suharso, llyas Nuryasin 


\begin{tabular}{|c|c|c|}
\hline 13. & Loket mencatat data Pembayaran Pelanggan & Eliminasi \\
\hline 14. & Menunggu aktifitas berikutnya & Eliminasi \\
\hline 15. & Pelanggan diberikan kwitansi pembayaran & Eliminasi \\
\hline 16. & $\begin{array}{l}\text { Pelanggan pulang dan menunggu petugas } \\
\text { pemasangan datang }\end{array}$ & Elim \\
\hline 17. & $\begin{array}{l}\text { Loket masuk ke hula untuk menyerakan data } \\
\text { tersebut }\end{array}$ & Elimin \\
\hline 18. & $\begin{array}{l}\text { Hula membuat laporan kebagian distribusi } \\
\text { kalau pelanggan sudah membayar }\end{array}$ & Elimi \\
\hline 19. & $\begin{array}{l}\text { Bagian distribusi mempersiapkan barang di } \\
\text { gudang untuk proses pemasangan }\end{array}$ & \\
\hline 20. & Menunggu instruksi selanjutnya & \\
\hline 21. & $\begin{array}{l}\text { Jika sudah lengkap bagian distribusi akan } \\
\text { melakukan pemasangan baru ke rumah } \\
\text { pelanggan }\end{array}$ & \\
\hline 22. & $\begin{array}{l}\text { Selesai pemasangan bagian Distribusi } \\
\text { membuat laporan untuk diserahkan kebagian } \\
\text { hula }\end{array}$ & \\
\hline 23. & $\begin{array}{l}\text { Bagian distribusi memberikan laporan ke } \\
\text { bagian Hula }\end{array}$ & \\
\hline 24. & Bagian Hula menyimpan laporan & \\
\hline 25. & $\begin{array}{l}\text { Bagian Hula masuk ke website data informasi } \\
\text { pelanggan. }\end{array}$ & \\
\hline 26. & $\begin{array}{l}\text { Bagian Hula mengisi data pelanggan baru dan } \\
\text { mengisi status menjadi pelanggan aktif. }\end{array}$ & \\
\hline
\end{tabular}

\subsection{Analisis Peluang Pemakaian TI}

Pada tahap ini dilakukan analisis peluang pemakaian Teknologi Informasi pada PDAM Kabupaten Mojokerto untuk mendukung rancangan ulang desain proses bisnis rekomendasi. Menemukan komponen teknologi informasi yang ada pada PDAM Kabupaten Mojokerto. Menganalisis peluang pemakaian ( $\mathrm{TI})$ teknologi informasi. Hasil wawancara tanggal 21 September 2018 dengan pegawai bidang IT untuk mencari data komponen teknologi informasi pada PDAM Kabupaten Mojokerto dan dari hasil ini mendapatkan data yang dicari. Berikut ini komponen teknologi informasi pada PDAM Kabupaten Mojokerto.

Tabel 3. Perangkat Keras

\begin{tabular}{ccc}
\hline No & Perangkat Keras & Jumlah Perangkat \\
\hline 1. & PC & 40 \\
2. & Print & 20 \\
3. & Scanner & 20 \\
4. & Wifi & 5 \\
\hline
\end{tabular}

Tabel 4. Perangkat Lunak

\begin{tabular}{cc}
\hline No & Perangkat Lunak \\
\hline 1. & Microsoft office \\
2. & Browser \\
3. & Website admin sistem informasi pengaduan. \\
4. & Website dan android sistem informasi baca meter. \\
5. & E billing untuk melihat tagihan dan data informasi pelanggan. \\
6. & Website untuk data pemutusan pelanggan. \\
7. & Software untuk locket dari Visual Basic. \\
\hline
\end{tabular}

Tabel 3 dan Tabel 4 menjelaskan komponen teknologi informasi yang ada pada PDAM Kabupaten Mojokerto. Identifikasi peluang-peluang TI sebagai enabler dituangkan berdasarkan pada sembilan kemampuan TI bagi organisasi sebagaimana dijelaskan oleh Davenport [2]:

1. Transactional: TI untuk transaksi pelayanan pada PDAM Kabupaten Mojokerto, Transaksi penanggulangan keluhan pelanggan, Transaksi laporan antar pegawai. 
2. Geographical: TI memungkinkan pertukaran sebuah informasi antara PDAM Kabupaten Mojokerto dengan pelanggan.

3. Automational: TI dapat memberikan sebuah peringatan jika ada masyarakat yang melakukan Pengaduan, Maupun pemasangan baru pelanggan.

4. Analytical: TI dapat memberikan analisis tentang berbagai informasi seperti Jumlah pengaduan dari pelanggan, Jumlah laporan pegawai.

5. Informational: TI dapat memberikan informasi tentang PDAM Kabupaten Mojokerto seperti Data pegawai, Data visi dan misi, data laporan pegawai, data keluhan pelanggan.

6. Sequential: TI mampu menyederhanakan proses manual yang tidak memberikan nilai tambah dan berbelit.

7. Knowledge Management: TI dapat mengambil dan menyebarkan sebuah pengetahuan seperti menyebarkan informasi gangguan air, SOP perusahaan, informasi biaya "detail tarif" yang diberlakukan untuk pelanggan.

8. Tracking: TI mampu melacak sebuah status contohnya status komplain atau pengaduan dari masyarakat dan sebagainya.

9. Desintermediation: TI mampu digunakan untuk alat berkomunikasi dengan pelanggan misalnya dengan email, web dan sebagainya.

\subsection{Rekomendasi}

Proses Bisnis Rekomendasi Pemasangan baru, Pada proses pemasangan baru dirancang sesuai dengan analisis alternative rancangan ulang yang sudah dilakukan eleminasi dan otomatisasi, langkah selanjutnya dilakukan penyesuaian dengan analisis peluang-peluang pemakaian teknologi informasi sehingga menghasilkan proses rekomendasi pemasangan baru.

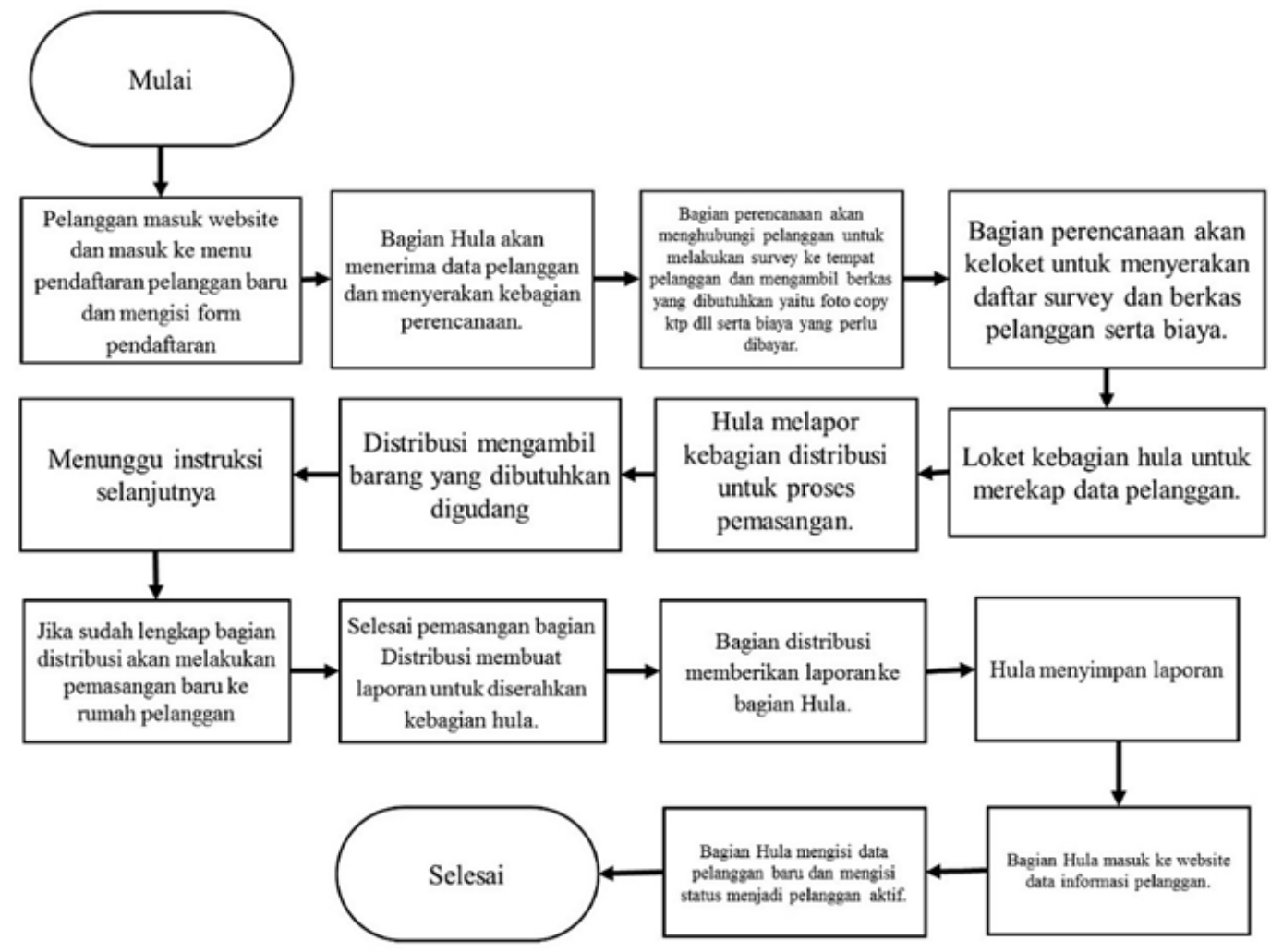

Gambar 3. Proses Bisnis Rekomendasi Pemasangan Baru

Gambar 3 adalah proses rekomendasi pemasangan baru pelanggan dimana pada proses ini sudah dilakukan analisis alternative rancangan ulang dengan menghilangkan proses yang tidak memberikan nilai tambah, mengotomatisasi proses dan analisis peluang pemakaian teknologi informasi disesuaikan dengan TI levers. Dimana pada proses rekomendasi pelanggan tidak perlu datang ke kantor untuk pemasangan baru PDAM tetapi bisa langsung mengirim permintaan secara online. 
Proses rekomendasi yang sudah dirancang selanjutnya dilakukan tabel pemetaan standar ASME dan pengujian efisiensi throughput pengujian waktu pelayanan secara keseluruhan. Pengujian uji efisiensi throughput hanya dilakukan pada proses yang berhubungan dengan waktu pelayanan. Berikut ini tabel pemetaan standar ASME dari proses rekomendasi dan hasil efisiensi throughput.

Tabel 5. Peta Proses Standar ASME Pemasangan Baru

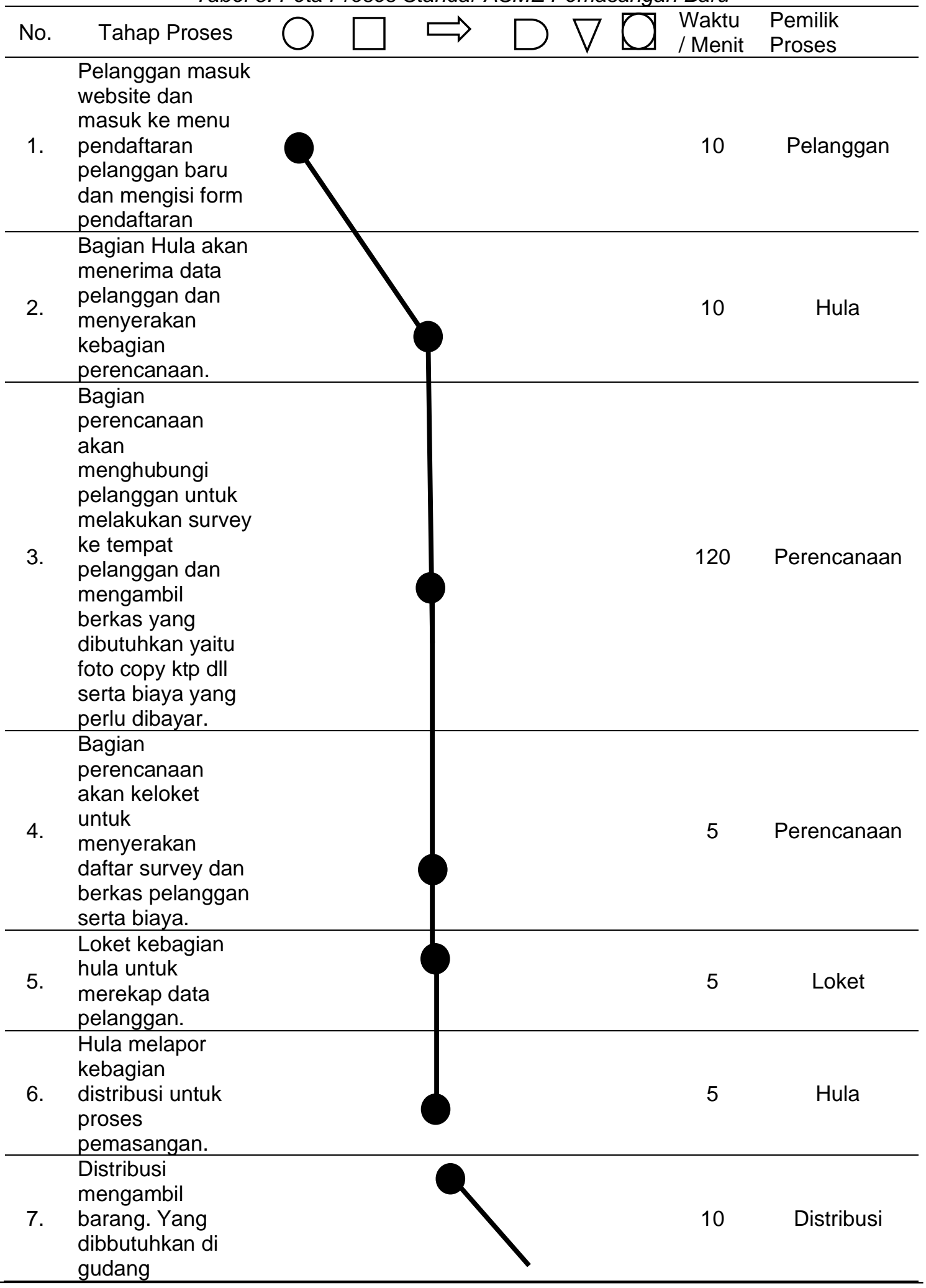

REPOSITOR, Vol. 2, No. 5, Mei 2020: 635-648 


\begin{tabular}{l} 
8. $\begin{array}{l}\text { Menunggu } \\
\text { instruksi } \\
\text { selanjutnya }\end{array}$ \\
\hline $\begin{array}{l}\text { Jika sudah } \\
\text { lengkap bagian } \\
\text { distribusi akan } \\
\text { melakukan } \\
\text { pemasangan baru } \\
\text { ke rumah } \\
\text { pelanggan. }\end{array}$ \\
$\begin{array}{l}\text { Selesai } \\
\text { pemasangan } \\
\text { bagian Distribusi } \\
\text { membuat laporan } \\
\text { untuk diserahkan } \\
\text { kebagian hula. }\end{array}$ \\
$\begin{array}{l}\text { Bagian distribusi } \\
\text { memberikan } \\
\text { laporan ke bagian } \\
\text { Hula. }\end{array}$ \\
$\begin{array}{l}\text { Bagian Hula } \\
\text { Menyimpan } \\
\text { laporan }\end{array}$ \\
$\begin{array}{l}\text { Bagian Hula } \\
\text { masuk ke website } \\
\text { data informasi } \\
\text { pelanggan. }\end{array}$ \\
$\begin{array}{l}\text { Jumlah Tahap } \\
\text { Total Waktu }\end{array}$
\end{tabular}

Tabel 5 adalah tabel peta proses standar ASME rekomendasi Pemasangan Pelanggan Baru. Pada tabel ini pelanggan dapat mengajukan pemasangan baru secara online dan mengurangi proses yang tidak memberikan nilai tambah. Selanjutnya dilakukan uji efisiensi throughput. Berikut ini uji efisiensi throughput pada peta standar ASME proses bisnis rekomendasi pemasangan baru.

$$
\begin{gathered}
\text { efisiensi throughput }=\frac{3070}{3070+180} \times 100 \% \\
=94,46 \%
\end{gathered}
$$

Hasil uji efisiensi throughput pada proses bisnis rekomendasi pemasangan baru memberikan presentase yang tinggi yaitu $94,46 \%$ dan sisanya adalah $5,54 \%$ waktu pelayanan dalam sistem tidak berjalan. Pada pengujian efisiensi throughput sebelumnya pada proses rekomendasi pemasangan baru memberikan hasil presentase yang kecil karena pada proses sebelumnya terlalu banyak proses yang tidak efisien dan membutuhkan waktu yang lama. Pada saat dilakukan analisis alternative rancangan ulang maka proses yang awalnya rumit dan tidak memberikan nilai tambah dieliminasi dan juga dilakukan otomatisasi pada proses sehingga dapat membantu proses agar lebih cepat.

\subsection{Perbandingan Efisiensi Throughput}

Tabel 6. Perbandingan Proses Bisnis Pemasangan Baru

\begin{tabular}{llcccc}
\hline No. & Proses Bisnis & $\begin{array}{c}\text { Efisiensi } \\
\text { Throughput } \\
\text { Awal }\end{array}$ & $\begin{array}{c}\text { Efisiensi } \\
\text { Throughput } \\
\text { Rekomendasi }\end{array}$ & $\begin{array}{c}\text { Kecepatan } \\
\text { Proses Awal }\end{array}$ & $\begin{array}{c}\text { Kecepatan } \\
\text { Proses } \\
\text { Rekomendasi }\end{array}$ \\
\hline 1. $\begin{array}{l}\text { Proses Bisnis } \\
\text { Pemasangan Baru }\end{array}$ & $30,41 \%$ & $94,46 \%$ & 12690 menit & 3250 menit \\
\hline
\end{tabular}


Pada tahap ini dilakukan perbandingan waktu pelayanan secara keseluruhan pada proses bisnis awal dan proses bisnis rekomendasi. Tabel 6 diatas adalah tabel perbandingan antara proses bisnis awal dan proses bisnis rekomendasi.

\subsection{Solusi}

Pada tahap solusi menghasilkan contoh tampilan aplikasi berbasis web yang dapat membantu proses rekomendasi pada PDAM Kabupaten Mojokerto untuk mencapai tujuan Business Process Reenginering. Gambar 4 berikut ini contoh tampilan aplikasi untuk membantu proses bisnis rekomendasi pemasangan baru.
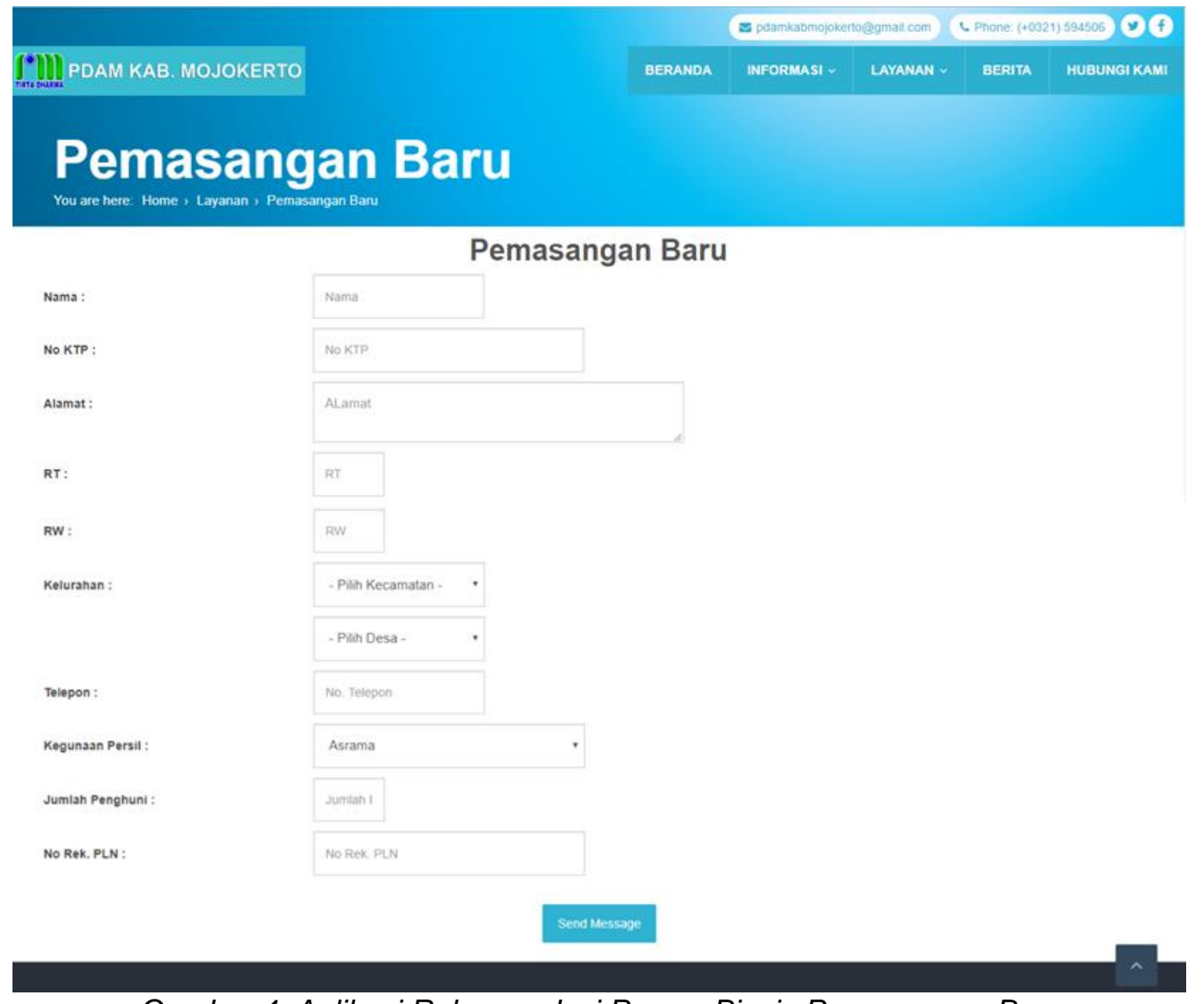

Gambar 4. Aplikasi Rekomendasi Proses Bisnis Pemasangan Baru

Contoh tampilan Proses bisnis rekomendasi pemasangan baru disesuaikan dengan kebutuhan awal dimana pelanggan dapat melakukan pemasangan baru secara online. Pelanggan masuk form pemasangan baru dan mengisi identitas diri seperti Nama, No. KTP, alamat, RT, RW, Kelurahan, Telepon, Kegunaan Persil, Jumlah Penghuni, dan No. Rek. PLN. Data pelanggan yang sudah dikirim akan masuk ke dalam website admin pemasangan baru dan bagian Hula akan menerima data pelanggan baru seperti ditunjukkan pada Gambar 5 berikut.
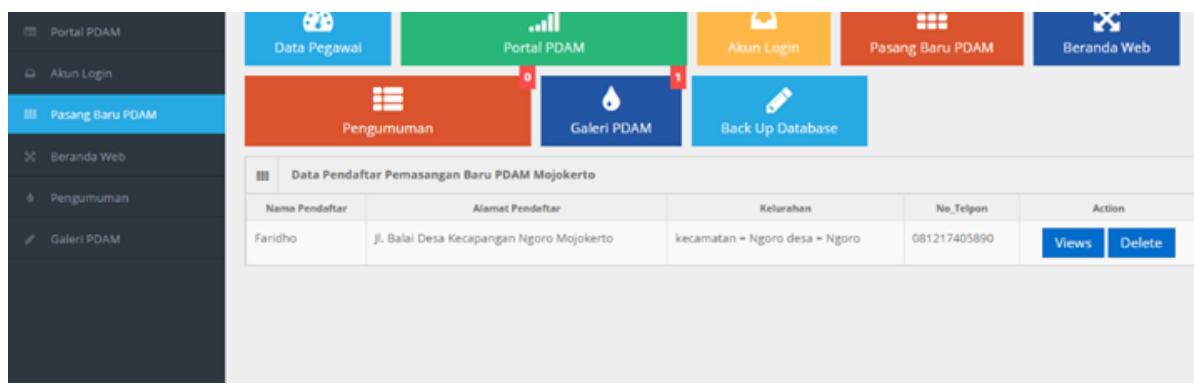

Gambar 5. Website Rekomendasi Halaman Admin Proses Bisnis Pemasangan Baru

REPOSITOR, Vol. 2, No. 5, Mei 2020: 635-648 


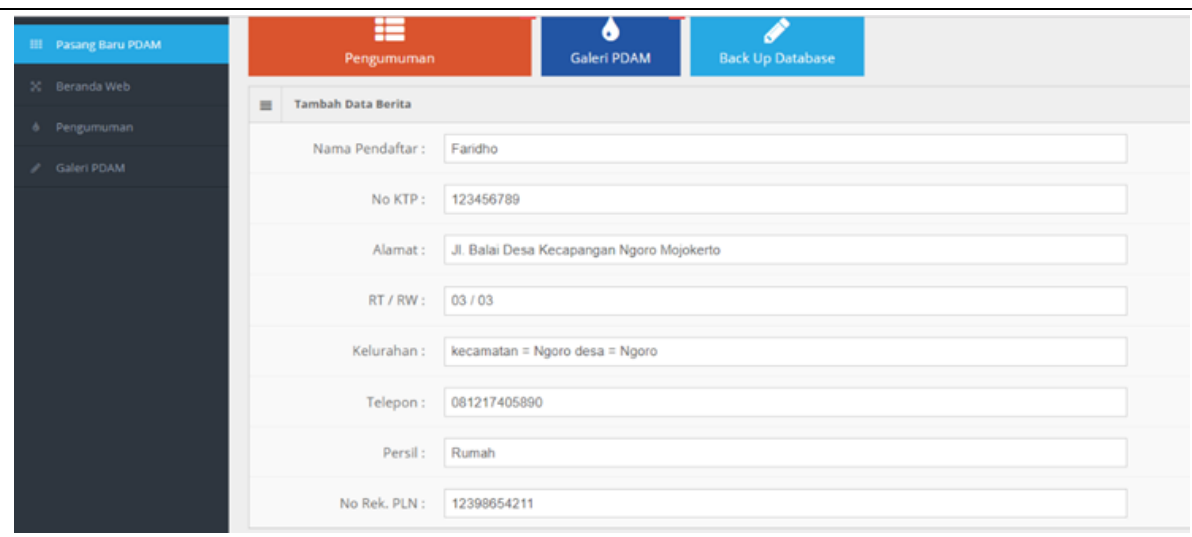

Gambar 6. Website Admin Rekomendasi Melihat Data Pelanggan Baru

Gambar 5 dan Gambar 6 adalah website rekomendasi halaman admin untuk proses bisnis pemasangan baru dimana setelah pelanggan baru mengisi data pada website halaman user maka data tersebut akan masuk pada halaman admin seperti pada Gambar 5 dan Gambar 6.

\section{Kesimpulan}

Business Process Reenginering mampu merubah proses yang lama ke proses yang baru yaitu pada tahapan rekomendasi sehingga mendapatkan proses yang lebih efisien dalam hal pelayanan waktu. Melakukan penyempurnaan desain proses dengan cara eliminasi yaitu penghilangan proses yang tidak memberikan nilai tambah dan automate yaitu proses yang manual diubah menggunakan aktivitas bantuan komputer. Teknologi Informasi berperan sebegai pendukung tahapan rekomendasi sehingga mendapatkan perubahan proses bisnis yang signifikan.

Business Process Reenginering mampu mendapatkan perbedaan antara proses lama dan proses yang baru pada tahapan rekomendasi dari segi pelayanan, kecepatan dan biaya. pada proses bisnis pemasangan baru dilakukan uji efisiensi throughput dengan hasil pada proses bisnis lama $30,41 \%$ dan pada proses baru pada tahapan rekomendasi menghasilkan $94,46 \%$. Proses rekomendasi lebih unggul karena waktu pelayanan $94,46 \%$ berjalan dengan baik dengan kecepatan 3250 menit.

Business Process Reenginering bisa memberikan rancangan model bisnis rekomendasi yang baru yang sudah dilakukan analisis alternative rancangan ulang dan analisis peluang pemakaian teknologi informasi. Menghasilkan aplikasi pendukung yaitu aplikasi berbasis web yang memudahkan proses bisnis rekomendasi, Aplikasi sebagai pendukung proses bisnis rekomendasi agar proses rekomendasi dapat berjalan dengan maksimal.

\section{Referensi}

[1] Agustin. Fhery, "Bussiness Process Reengineering Sistem Presensi Mahasiswa Berbasis Waktu Secara Paperless (Study Kasus: Stmik Potensi Utama)", Vol. 6 No. 3 Hal. 159-170, 2014.

[2] A. D. Yulianto, "Perancangan Sistem Informasi Kemetrologian dalam Pendekatan Business Process Reengineering untuk Pelayanan Tera," Jnteti, vol. 3, no. 3, pp. 174-178, 2014.

[3] D. D. Wimpertiwi, "Konsep Business Process Reengineering Untuk Memperbaiki Kinerja Bisnis Menjadi Lebih Baik: Studi Kasus Perusahaan Susu Kedelai ' Xyz ,'” Binus Bus. Rev., vol. 5, no. 2, pp. 658-668, 2014.

[4] M. Attaran, "Exploring the relationship between information technology and business process reengineering," Inf. Manag., vol. 41, no. 5, pp. 585-596, 2004.

[5] M. S. Rejeki and A. Tarmuji, "Membangun Aplikasi Autogenerate Script Ke Flowchart Untuk Mendukung Business Process Reengineering," Peranc. Sist. Inf., vol. Volume 1, pp. 448456, 2013.

[6] Sulaiman. Agus, "Analisis dan Rekayasa Ulang Proses Bisnis Sistem Pembelian pada PT XYZ", ULTIMA InfoSys, Vol. V, No. 1, 2014

[7] S. Wildan dan Damar Arya P.M., "Rekayasa Ulang Sistem Permintaan Informasi Pada Kejaksaan Negeri Batu," Universitas Muhammadiyah Malang, 2018

[8] R. D. Richardus Eko indrajit, "Business Process Reengineering", 2002. 
REPOSITOR, Vol. 2, No. 5, Mei 2020: 635-648 